Georgy Smirnov, Tatyana Vyatchanina

\title{
THE BERGHOLTZ COLLECTION: \\ ARCHITECTURAL DRAWINGS OF THE \\ PALACES IN JELGAVA AND RUNDALE \\ FROM NATIONALMUSEUM (STOCKHOLM)
}

12 architectural drawings of two prominent palaces in Courland (now Latvia), namely in Mitau (Jelgava) and Ruhental (Rundale) are to be found in the Tessin-Hårleman Collection (THC) of Nationalmuseum in Stockholm, one of the most famous gatherings of architectural drawings in Europe. They are kept in the so called Bergholtz collection which is a part of THC. The drawings of two Courland palaces make this collection of special interest for the art of the Baltic region.

Who was the creator of the collection, what was the reason to compile it and what other drawings are stored there - these are the first questions to be answered in this article. Friedrich Wilhelm von Bergholtz (1699-1771) is a well-known person in Russian history of the $18^{\text {th }}$ century. Born in the German Duchy of Holstein, he made three long-term visits to the Russian empire during the first half of the century, spending about 15 years there in total. The first stay (1709-1714) was connected with his father's military service for Peter the Great, as a general-lieutenant, who took part in the Northern war. In 1721-1727 Friedrich Wilhelm von Bergholtz stayed at the 
court of Karl Friedrich, the Duke of Holstein-Gottorp; first as a Kammerjunker, then as a Kammerherr. In 1721-1725 he accompanied the duke during his visit to Russia as a bridegroom of Anna Petrovna, the elder daughter of Peter the Great. After the wedding, which took place in 1725, Bergholtz stayed in Russia with the duke and his wife until their departure to Kiel, the capital of Holstein, in 1727. Anna Petrovna died in 1728 and her husband in 1739, after that Bergholtz was appointed a tutor of their son Karl-Peter-Ulrich (1728-1762). In 1742 the latter was invited by his aunt the empress Elizaveta Petrovna to Russia as the heir to the Russian throne. After her death in 1761 he became the emperor under the name of Peter III. Bergholtz stayed with the future emperor as his tutor until 1746, when he was dismissed and left Russia. Until his death in 1771 Bergholtz lived in Wismar (Mecklenburg), which at the time, according to the Peace of Westphalia (1648), belonged to Sweden.

In Russian historiography Bergholtz is highly appreciated as the author of a diary which he wrote during his second visit to Russia in 1721-1726. This diary, first published in Russian in the mid-19 $9^{\text {th }}$ century ${ }^{1}$, is considered a precious source for the study of everyday life of Russian high society in the last years of Peter the Great's reign, not least of the tsar himself. Several pages are dedicated to the stay of Bergholtz in Revel (Tallinn) together with Karl Friedrich during a visit there of Peter the Great in July 1723. A brief description of the palace and garden in Katharinenthal (Kadriorg) may be of definite interest. For art historians, Bergholtz is valued mainly for his extremely rich and diverse collection of architectural drawings, which cannot be overestimated. The first mention of the Bergholtz collection is found in an inventory of the Royal Library in Stockholm (1790). As part of the Library it was transferred to the Royal Museum, which was founded in 1792, and in 1866 renamed the National Museum (Nationalmuseum).

The Bergholtz collection remained unknown to the public until the mid-20 $0^{\text {th }}$ century. In 1950s it was rediscovered and studied by the Swedish scholar Björn Hallström, who proved that it was assembled by Bergholtz, who also the author of all inscriptions on most of the drawings. In 1963, Hallström published a complete catalogue of the collection in English, although with a very limited number of black and white illustrations ${ }^{2}$.

The circumstances of compiling the collection and reasons for it are rather obscure. All assumptions made by different Russian authors (regarding Bergholtz either as a connoisseur, as an amateur of architecture, or even as a spy) remain a mere guesswork. It is only clear that the greater part of the collection was compiled during Bergholtz's final stay in Russia, even though some drawings might have been acquired during his previous visit, or could have been procured later due to correspondence with Jakob Stählin, the Secretary of the Academy of Arts and Sciences in St Petersburg. How and when the collection came to Stockholm is not known either. According to Björn Hallström's suggestion, Bergholtz left it to the Swedish Royal House in gratitude for the financial help he had received from Stockholm while living in Wismar ${ }^{3}$.

The greater part of the Bergholtz collection, dedicated to St Petersburg and its surroundings became known to Russian public due to the exhibition held in the State Hermitage in September $1963^{4}$. In the following decades, especially during the last 20-25 years, this part of the collection was thoroughly studied by St Petersburg's scholars, mostly by Yuriy Denisov, Ekaterina Stanyukovich-Denisova (Baryshnikova) $^{5}$ and Alexandr Krasnolutsky. In 2018, the latter published a complete catalogue of St Petersburg's part of the collection with illustrations of high quality ${ }^{6}$.

The drawings that deal with the architecture of St Petersburg show panoramas of buildings on the streets and embankments, and separate houses, which all together make a magnificent and precise representation of the capital of Russian empire in mid-1740s. These drawings have become one of the main sources for the study of St Petersburg architecture in the time of Peter the Great and his

2 Björn H. Hallström, Russian architectural drawings in the Nationalmuseum (Stockholm: Nationalmuseum, 1963)

3 Ibidem, 5.

4 Yuriy Denisov, Arhitektura Peterburga pervoy poloviny XVIII veka iz sobraniya Nazionalnog muzeya $v$ Stokgolme (prospect vystavki) (Leningrad: Gosudarstvennyy Ermitazh, 1963).

5 She is the author of a series of articles dealing with the architecture of St Petersburg in connection with the architectural drawings from the Bergholtz collection, published in 1996-2012.

6 Aleksandr Y. Krasnolutskiy, Arhitekturnye chertezhi i plany Sankt-Peterburga (1730-e1740-e gody) iz kollektsii Fridriha Vilgelma Berhgoltsa, 2 vols. (Sankt Petersburg: Kriga, 2018) 
successors up to the reign of Elizaveta Petrovna. They depict the architecture of the new Russian capital, which decisively broke with the medieval past and followed the principles of European art of modern times, influenced mainly by the late Baroque architecture of Holland, Germany and France.

All other drawings, with total number of 174, refer to Moscow, to several provinces of the Russian empire and to the duchy of Courland a vassal state of the Polish-Lithuanian Commonwealth, annexed by Russia during the Third Partition of Poland in 1795. A majority of the drawings mentioned above are compiled in an album ${ }^{7} .30$ other drawings are kept as separate sheets ${ }^{8}$. This part of the Bergholtz collection is much less known and have had only sporadic reflections in some publications ${ }^{9}$. As for the sheets with two palaces in Courland - they have never been mentioned in any publication before, except for 4 drawings used as illustrations, with bad quality, and with false references to the source ${ }^{10}$

Consistent with the whole collection, the drawings depicting Moscow and provincial towns are different in graphic technique and unequal in artistic quality. In this regard they may be divided in two principal groups. A smaller part consists of design or measurement drawings made in pencil or ink and in watercolour. No doubt they were executed by architects or their apprentices and journeymen. But a larger number of the sheets are pencil drawings that represent copies of projects or fixating sketches, which reveal a nonprofessional hand. Nonetheless, almost all drawings of the latter part are characterized by keen and precise attention to details of the façades and elevation decoration, regardless of their artistic quality. This peculiar feature makes these drawings of no less value for the study of architecture than those made by professionals.

7 Nationalmuseum, Stockholm [NM THC] 9076.

8 NM THC 166, 167, 168, 170, 430, 432, 433, 491, 492, 493, 494, 508, 697, 698, 699, 700, 701, $1520,1521,1522,1523,1524,1525,1526,1527,1528,1529,1530,2477,4756$.

9 E.g. Olga S. Evangulova, Dvortsovo-parkovye ansambli Moskvy pervoy poloviny XVIII veka (Moskva: Izd-vo Moskovskogo universiteta, 1969), $52-54$, 70; Georgy K. Smirnov, Svod 2002), 180-181; Ekaterina A. Tukhmeneva, Iskusstvo triumfalnyh vorot $v$ Rossii pervoy poloviny XVIII veka (Moskva: Progress-Traditsija, 2005), ill. 1 and 4; Georgy K. Smirnov, "Grafika iz sobraniya Berhgolza: arhitektura Moskvy", Sobranie, 3 (2006), 8-13.

10 Konstantin V. Malinovskiy, Bartolomeo i Francesco Rastrelli (Sankt Petersburg, Izdatelstvo Levša "Sankt-Peterburg", 2017), 115, 116, 122. In this book the drawings from the Bergholtz collection are incorrectly said to be from the Albertina Museum (Vienna)
Professional drawings were obtained by Bergholtz - as one may only speculate - in different ways. He could have bought or exchanged them, received them as gifts, etc. Unfortunately, to this day, we have not obtained a single documental note on this point. The same is true about the author (or to be more correct - the authors) of the second set of drawings. All drawings of this kind made in St Petersburg according to Yuriy Denisov - belong to one hand and could have been made by a person who accompanied Bergholtz and who possibly had some special knowledge of architecture but was not a skilful craftsman ${ }^{11}$. Many drawings from the Moscow and provincial part of the collection could be attributed to the hand of this unknown author. Still, some of the drawings are set apart by different manner of execution and by different artistic quality - either of higher or of lower level, including a few very primitive ones. We agree with Yuriy Denisov that Bergholtz himself could hardly be the author of these drawings. At the same time, the collection assembled by Bergholtz agrees with his persona of an eye-witness with an acute and detailed manner of observation of the surrounding reality and events as we know from his Diary of 1721-1726. Besides the authorship, the collection's owner is reflected in inscriptions in German or - much more rarely - in French, which accompany almost all the sheets. These inscriptions explain what is represented on the drawings, in some cases rather informatively and with detailed legends.

Apart from St Petersburg, Moscow has the widest and most detailed representation of its architecture in the Bergholtz collection. But contrary to drawings dedicated to St Petersburg which represent unique and entire panoramas of the main streets and embankments of the northern capital of Russia, the Moscow part of the collection consists of a great number of separate buildings, ensembles or sites. The only exception is a watercolour depicting a panorama of Moscow ${ }^{12}$, embracing almost the whole territory of the old Russian capital. This magnificent veduta was most probably executed in early 1740 s. It seems to be the only drawing of the Bergholtz collection (apart from the drawings by F. Rastrelli, discussed further) which author is known at least by name as it is signed: Fecit Peter Schwentzsohn. Corporal. The

11 Denisov, Arhitektura Peterburga pervoy poloviny XVIII veka iz sobraniya Nazionalnogo muzeya $v$ Stokgolme (prospect vystavki.)

12 NM THC 9076, no. 1 . 


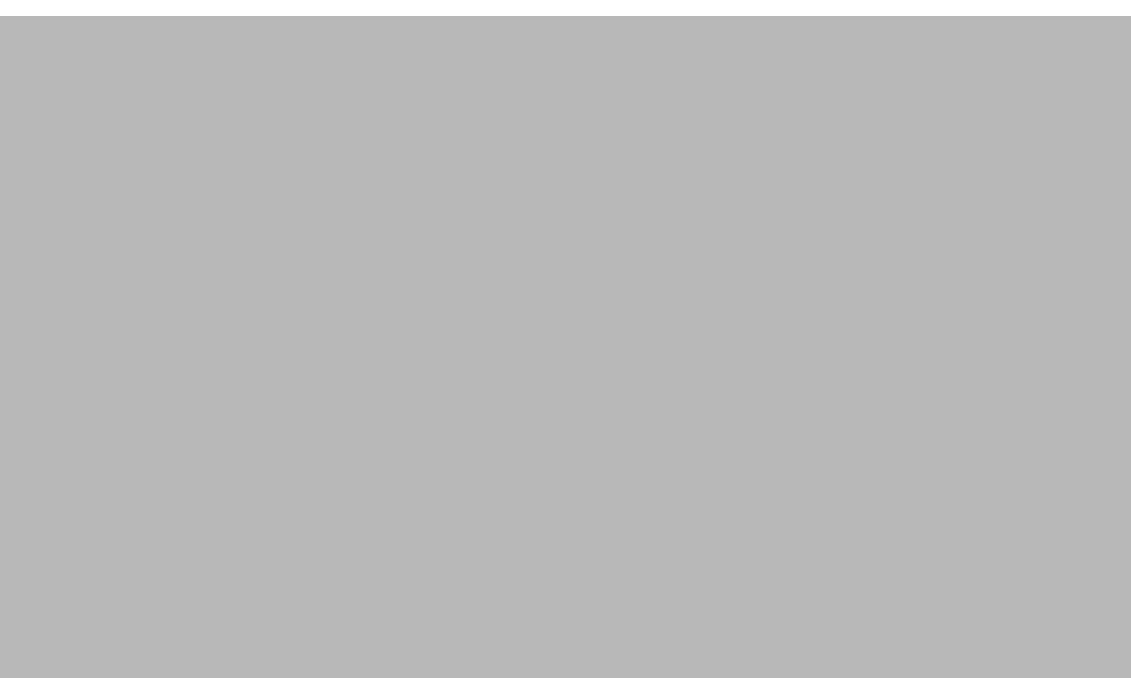

FIG. 1. PETER SCHWENTZSOHN, VIEW OF MOSCOW (INK, WATERCOLOUR), $18 \times 41,5$. NM THC 9076, NO. 1.

drawing was made from a hill on the left side of the river Moscow. In the foreground of the drawing there are two small figures - one looking through a telescope, another making a sketch in an album settled on a hillside admiring a vision of a fabulous city so different from all they had seen before in native Europe.

More than 20 drawings of the Bergholtz collection are dedicated to the buildings situated in the Kremlin. They include views taken from different sites of the Kremlin's territory, a plan of its part, façades of the churches and other buildings, walls and towers among them. In addition to the Kremlin, the Bergholtz collection enriches our knowledge of Moscow architecture - not only of the first half of the $18^{\text {th }}$ century but of the previous centuries as well. The most significant are the drawings that concern dwelling houses and city residences of the representatives of famous old Russian families - Trubetskoys, Sheremetevs, Tatishevs, Dolgorukiys, Gagarins, Saltykovs and others. Some houses depicted on the drawings belonged to numerous successors from other countries who made their career in the time

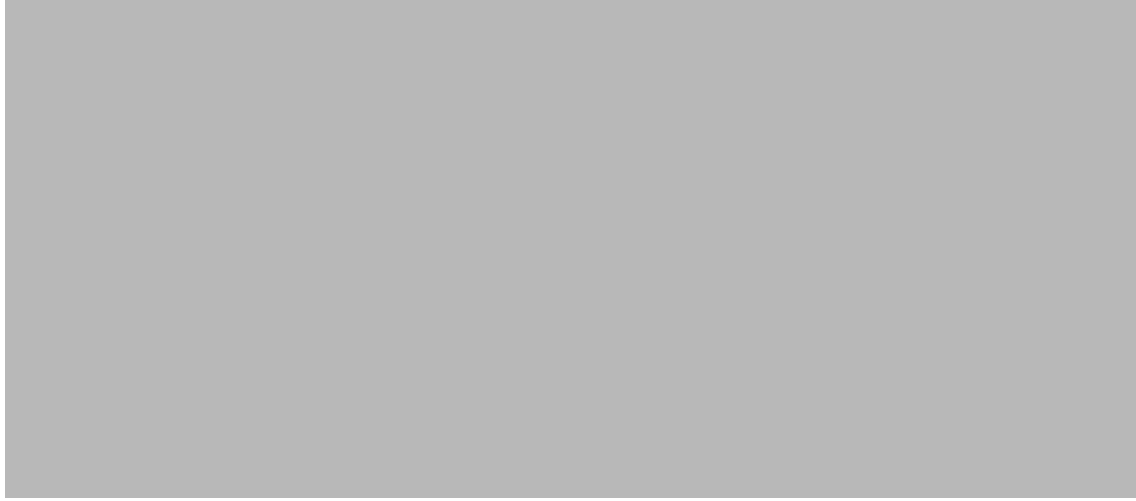

FIG. 2. THE HOUSE OF CHIEF OF POLICE TATISHEV IN MOSCOW (INK, WATERCOLOUR), 14, $\times 38,8$. NM THC 9076 , NO. 90

of Peter the Great - Lithuanian Pavel Jaguzhinskiy who became the general prosecutor of the Senate, diplomat Savva Raguzhinskiy, successor of Croatian princes, admiral Franz Lefort, of Swiss origin, physician Nickolas Bidloo from Holland.

Some of these houses date back to the $17^{\text {th }}$ century and are typical for the late medieval Russian architecture, but the majority of them were built during the first decades of the $18^{\text {th }}$ century and followed the artistic tendencies of European Baroque architecture. One of the most famous dwelling houses erected in Moscow during the reign of Peter the Great was Franz Lefort's palace, which was rebuilt about 1708 by its new owner, a prominent associate of the tsar Alexandr Menshikov. The whole structure is well preserved to this day, but it lacks to a great degree the rich decoration of the court façades, which can be seen on the drawings in the Bergholtz collection ${ }^{13}$. For the study of early $18^{\text {th }}$ century architecture in Moscow, a drawing

13 NM THC 9076, no. 34:I, 34:II. 
depicting the main façade of the palace of the prince Matvey Gagarin built in the 1700s, is of great value ${ }^{14}$. It differs considerably from the early $19^{\text {th }}$ century engraving, which for a long time was considered to reflect the original appearance of the building. As a matter of fact, the original façade had much more elegant decoration, but it lacked the arcaded loggia, which was added much later. Among Moscow buildings of 1730s-1740s we should emphasize a sumptuous palace of the count Sheremetev ${ }^{15}$, and a more modest house of the chief of police Alexey Tatishev ${ }^{16}$. Different in character and in size, both buildings were decorated in the style similar to late Baroque architecture in Europe, which was widespread in Moscow during the reign of two empresses - Anna Ioannovna and Elizaveta Petrovna.

An important part of the Bergholtz collection concerning Moscow deals with churches and medieval monasteries, which were an integral part of the old capital of Russia and its outskirts. These are several churches dating back from the $16^{\text {th }}$ to early $18^{\text {th }}$ century, and 8 monasteries.

The architecture of different provincial regions of Russian empire is represented in a few drawings. As iconographic sources for the provincial architecture of the first half of the $18^{\text {th }}$ century are extremely rare, this part of the Bergholtz collection is of special importance. Two buildings in old Russian cities, namely in Tver and Tula, must be emphasized here. The archbishop's palace in Tver, built in 1738-1739 and totally reconstructed after the fire of 1763 , is depicted in three pencil drawings ${ }^{17}$, presenting the main façade of this huge building. No other images of the palace are known. The drawings reveal the dual character of the architecture typical of the period of the reign of the empress Anna Ioannovna. The lower part of the building with an open gallery has the traditional kind of wall decoration going back to the time before Peter the Great, while the upper storey is decorated in the Baroque style. Two very impressive drawings (ink, watercolour) depict merchant Semion Paltsov's house in $\mathrm{Tula}^{18}$, the city that is remarkable for a plethora of brick dwelling houses dating back to the first half and middle of the $18^{\text {th }}$ century. The drawings,

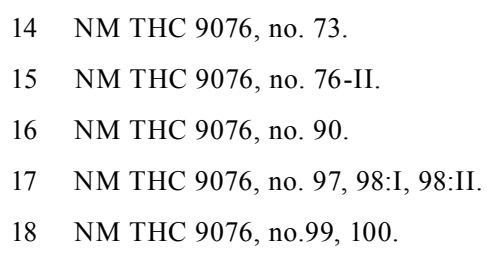

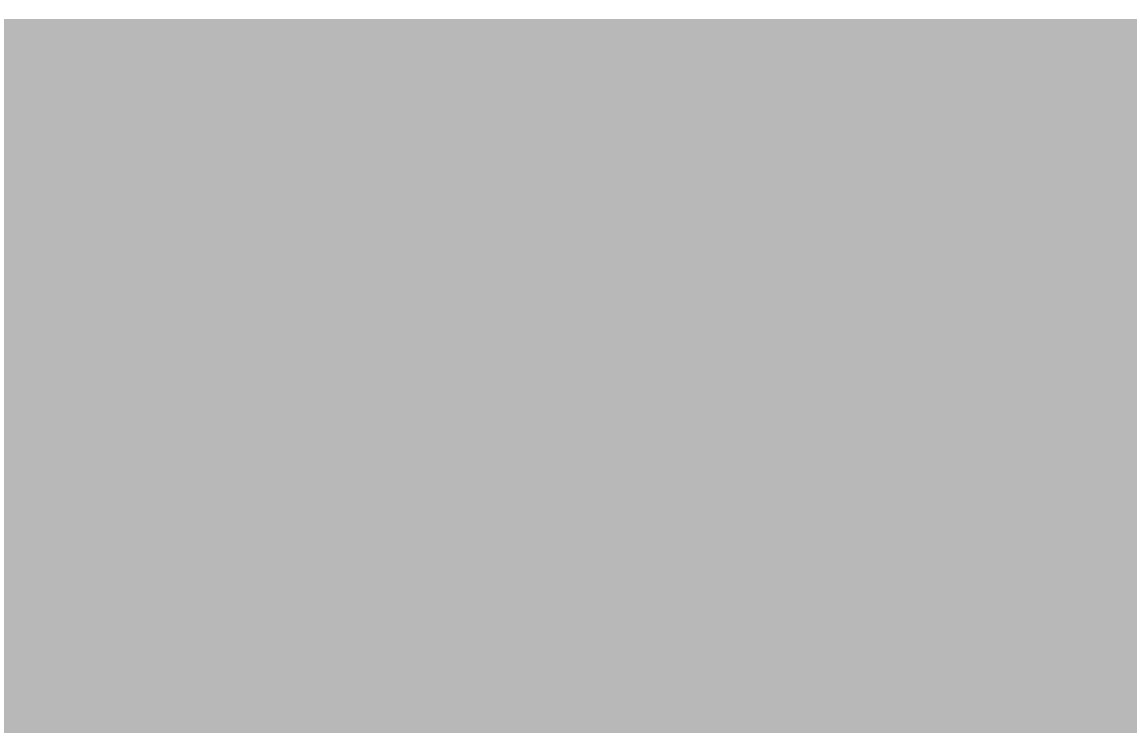

FIG. 3. THE HOUSE OF PALTSOV IN TULA (1744, INK, WATERCOLOUR), 30,5 × 48. NM THC 9076 NO. 99.

made in 1744, probably soon after the construction of the house, show the main façade and two plans revealing a representative building in the Baroque style in its provincial interpretation.

Finally, two palaces built in 1730 s by the great architect Francesco Rastrelli for the Duke of Courland Ernst Johann Biron will be discussed $^{19}$. The estate Gross Ruhental (Rundale) was purchased by Biron on the 26th of June 1735. In the same year a new palace instead of a castle of the previous owners was conceived. Francesco Rastrelli, court architect of the Russian empress Anna Ioannovna, was appointed as a designer of a palace. He arrived at Ruhental in August 1735. The project was ready in 9 months and the foundation stone was laid on the 24th of May 1736. When the palace received a roof in 1738 a city residence was started for Biron, who had become Duke

19 The following history of the creation of both palaces is mainly based on two bibliographical sources: Imants Lancmanis, Rundalskiy dvorets (Rundāle: Rundāles pils muzejs, 2012), 4-9; Malinovskiy, Bartolomeo i Francesco Rastrelli Malinovskiy, 114-125, 211-217. 


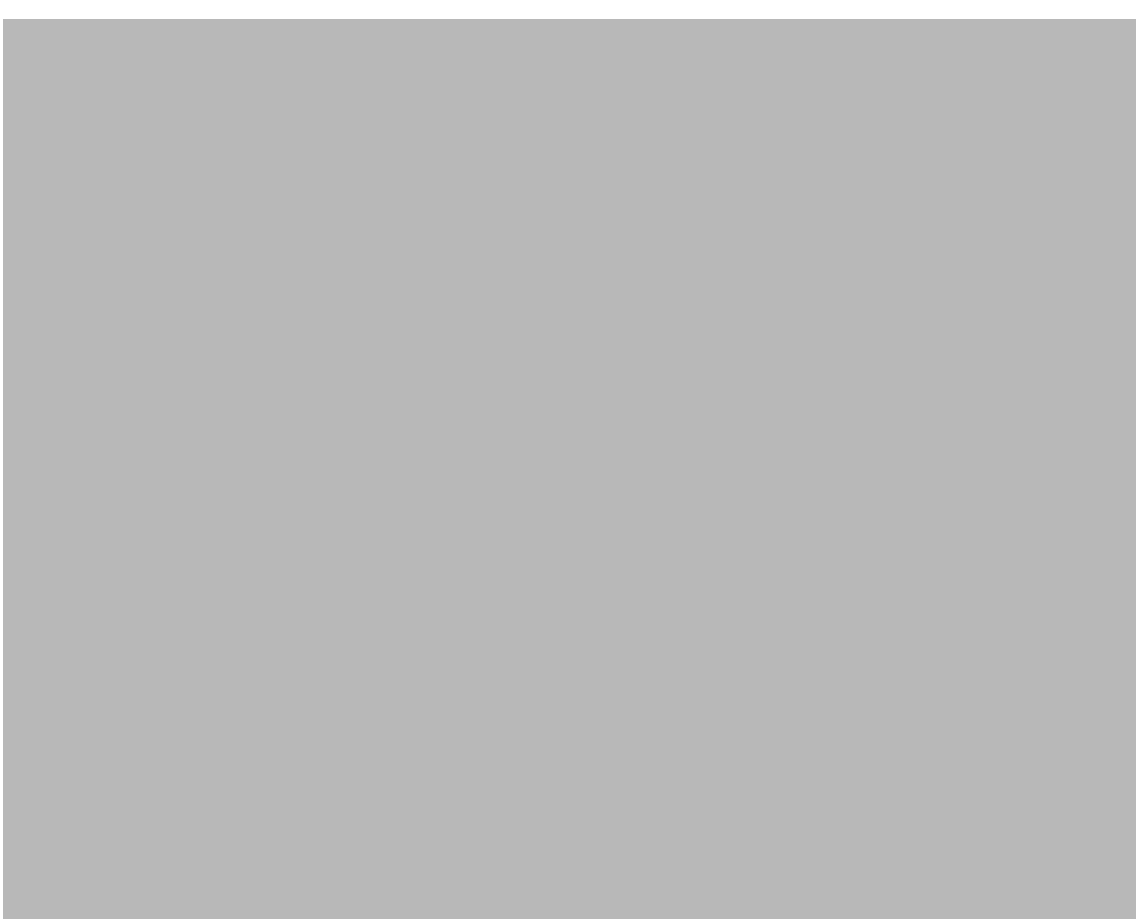

FIG. 4. RUHENTAL. THE PALACE AND THE GARDEN. GENERAL PLAN (INK, WATERCOLOUR), $45 \times 58,5$. NM THC 1524 .

of Courland in 1737, in Mitau (Jelgava), the capital of the Duchy, also according to Rastrelli's design. In spite of the difficulties connected with the simultaneous construction of two huge buildings, both palaces were almost finished by autumn 1740. After the death of Anna Ioannovna in October 1740, Biron became Regent under the infant emperor Ioann VI. However the arrest of Biron as a result of a palace coup and his further exile which lasted 22 years delayed the completion of both residences for many years. In 1762 Biron was returned from exile by Peter III and somewhat later restored by Catherine II to the ducal throne. Only after his return to Courland in 1763 could the palaces in Mitau and Ruhental be completed. The final work was mainly conducted under the guidance of Rastrelli, who arrived here in 1764 and obtained the post of oberintendant (senior manager) of the Duke's buildings. The architect had his residence in Courland, with some intervals, until 1770. In this period the palace in Ruhental was fully completed (1767); the city residence in Mitau was completed somewhat later, and was ready to receive the Duke's family $^{20}$ in 1772 .

Four drawings of the Bergholtz collection are dedicated to the city residence in Mitau and seven deal with the country summer residence in Ruhental. One more sheet, namely a project of the altar for the church, has a reference to both palaces as initiated for one of them and executed for the other. These drawings could have been purchased by Bergholtz while passing through Courland on his way from Holstein to St Petersburg in 1742, or on his way back to Wismar in 1746. Or else, they could have been acquired somehow in St Petersburg during his stay there as a tutor to the Great Duke KarlPeter-Ulrich (Piotr Fiodorovich). One cannot exclude the fact that Bergholtz was acquainted with Rastrelli and could get the drawings from the great master himself or from anyone of his circle.

Biron's summer residence in Ruhental is represented on seven sheets ${ }^{21}$ showing the general plan including formal French garden, hunting park with ray glades, stable yard and other household buildings. There are also 2 plans (of ground and first floors) and 4 façades of the palace. The latter show the northern façade with a gate tower, the southern façade facing the garden, the courtyard façade with cross sections of the side wings and the lateral façade. The drawings from the Bergholtz collection exactly or almost exactly correspond to the original projects, which are held in the collection of the Albertina Museum in Vienna ${ }^{22}$.

20 At that time the duke was the son of E. J. Biron Peter, who had got the power from his father on the 25th of November 1769 .

21 NM THC 1524, 1525, 1526, 1527, 1528, 1529, 1530. The sheets have inscriptions in French. They are as follow. N 1524: "Plan du Chateaux de Rouhendal avec le Jardin et les environs". N 1525: "Plan des Souterains, du Chateaux de Rouhendal". N 1526: "Plan du Chateaux de Rouhendal avec tous ces Batiments". N 1527: "Facade du coté de l'entre, du Pallais de Rouhendal". N 1528 "Facade de l'Exterieur du Pallais de Rouhendal que le Duc de Courland a fait Batir à quelque 1530: "Facade d'un des Ailes du Pallais Ducal de Rouhendal".

22 Albertina, Vienna, 79-2-5 N 5675 (general plan), 79-2-6 N 5676 (plan of the first floor and the stable yard), 79-2-7 N 5677 (plan of the ground floor), 79-2-8 N 5678 (façade of the main pavilion facing the courtyard with cross-sections of the side wings), 79-2-9 N 5679 (garden façade of the main pavilion), 79-2-10 N 5680 (lateral façade), 79-2-11 N 5681 (northern façade with a gate-tower). Only three of them (general plan, façade of the main pavilion facing the courtyard and northern façade) have been published in colour and with a good quality: Lancmanis, Rundalskiy dvorets, 7,8 . 

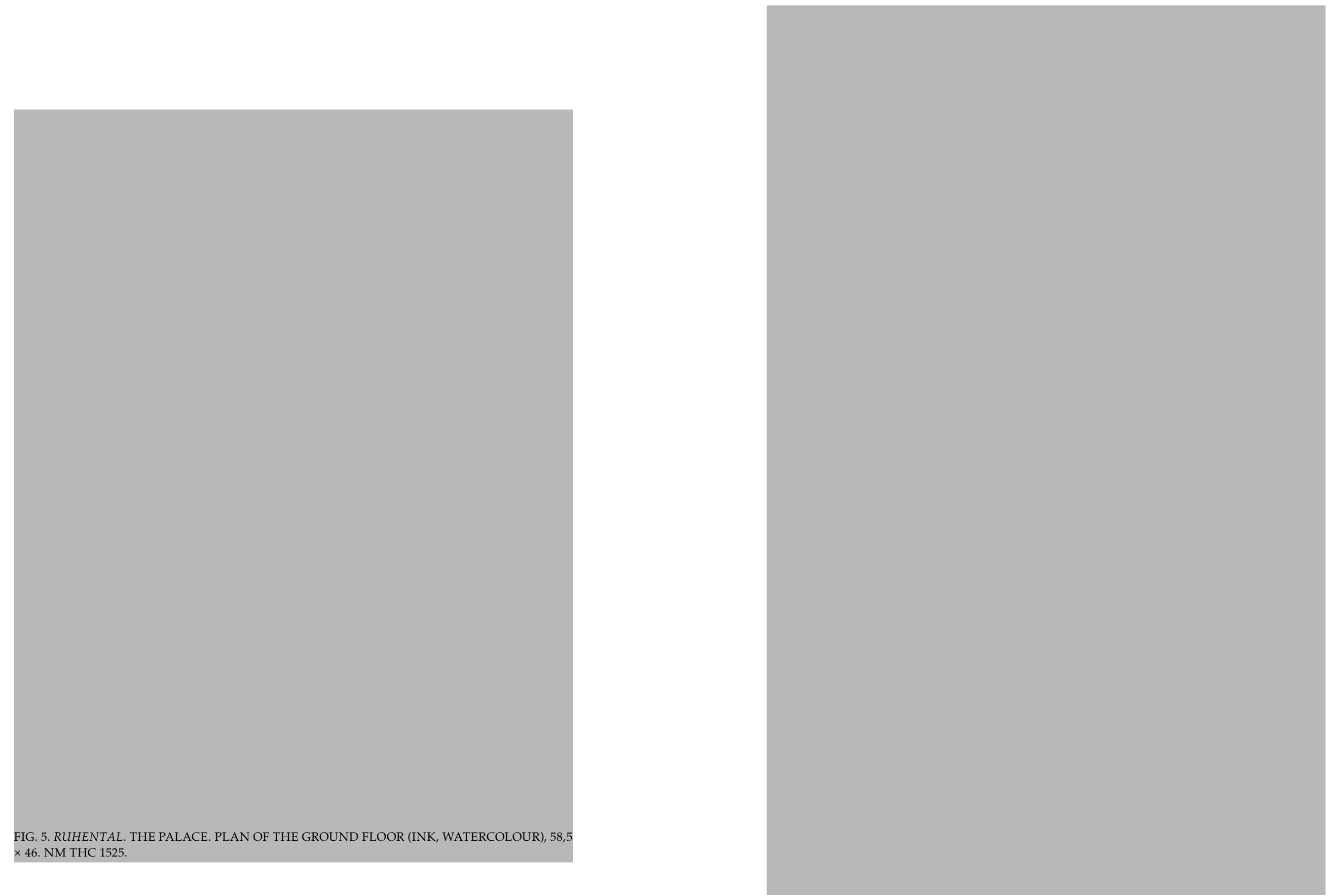


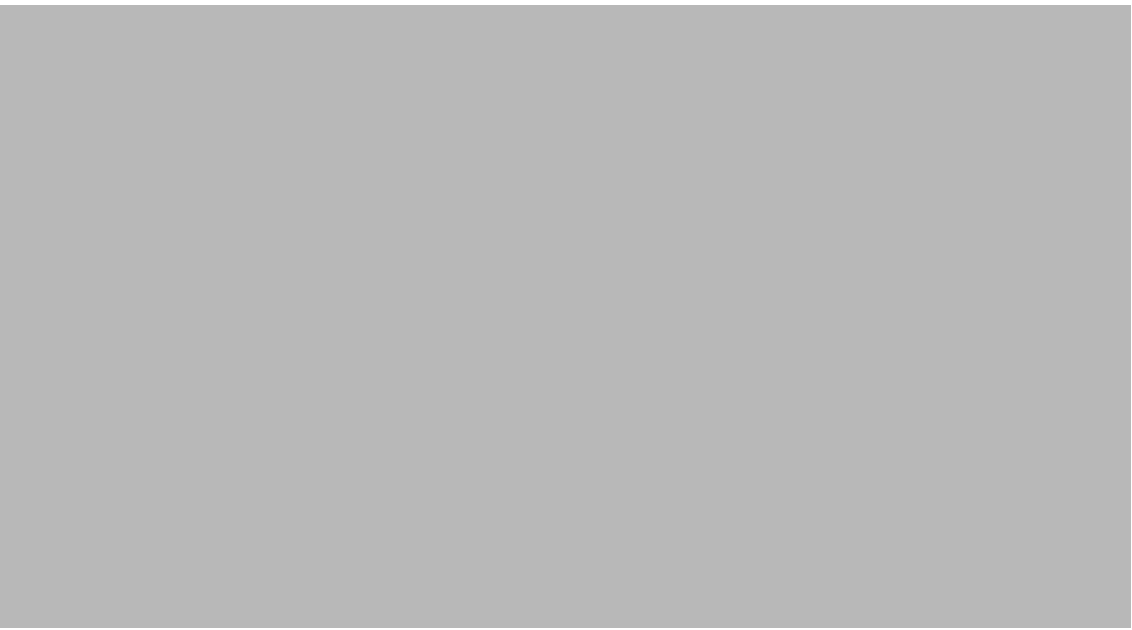

FIG. 7. RUHENTAL. THE PALACE. NORTHERN FAÇADE WITH A GATE-TOWER (INK, WATERCOLOUR), $43,5 \times 80$. NM THC 1527.

All the drawings from the Albertina Museum, except for the general plan, are approved by Biron. The inscription made with his hand is as follows: Dieses wird aprobiert. E.J. Biron ("This is approved. E.J. Biron"). Three drawings point to the authorship of Rastrelli bearing his name: De R. ${ }^{23}$ or De Rastrelly f..$^{24}$ Particle "de" means the architect's title of count, "f." obviously means "fecit". With high probability we may state that these sheets were signed by Rastrelli with his own hand.

Three Albertina drawings of Ruhental palace are dated: the general plan (1734) and two façades with the inscription De R. (1736). The latter dates are surely correct, but the first is not. Firstly, the estate of Ruhental was, as mentioned above, purchased by Biron in 1735 . Secondly, the inscription put in a cartouche, states the following: Plans General de toutes la Situation du Palais D'Eté Batit au Grand Ruhenthal pour Son Altésse Mg. Le Duc de Courlande à 5. Lieux de la Ville Mittèau.

23 Albertina, $79-2-8$ N $5678,79-2-10$ N 5680

24 Albertina, 79-2-9 N 5679

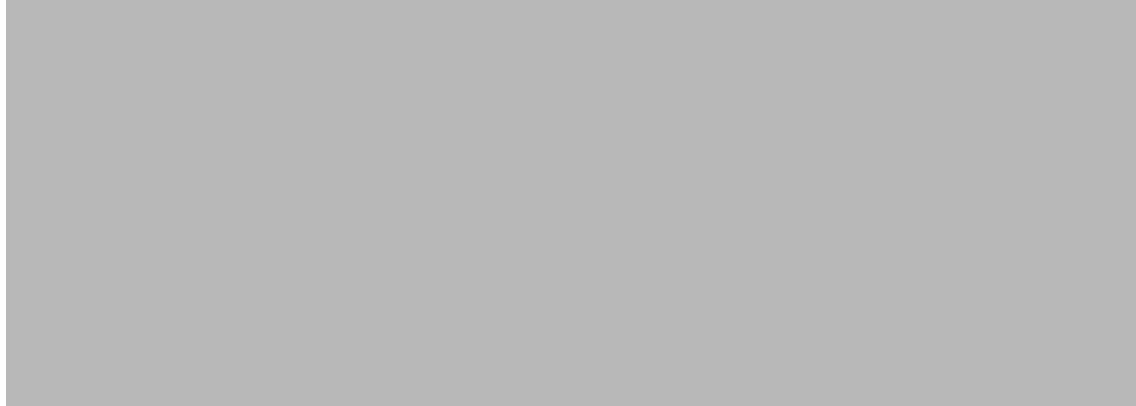

FIG. 8. RUHENTAL. THE PALACE. FAÇADE FROM THE GARDEN SIDE (INK, WATERCOLOUR) $45 \times 58,5$. NM THC 1528.

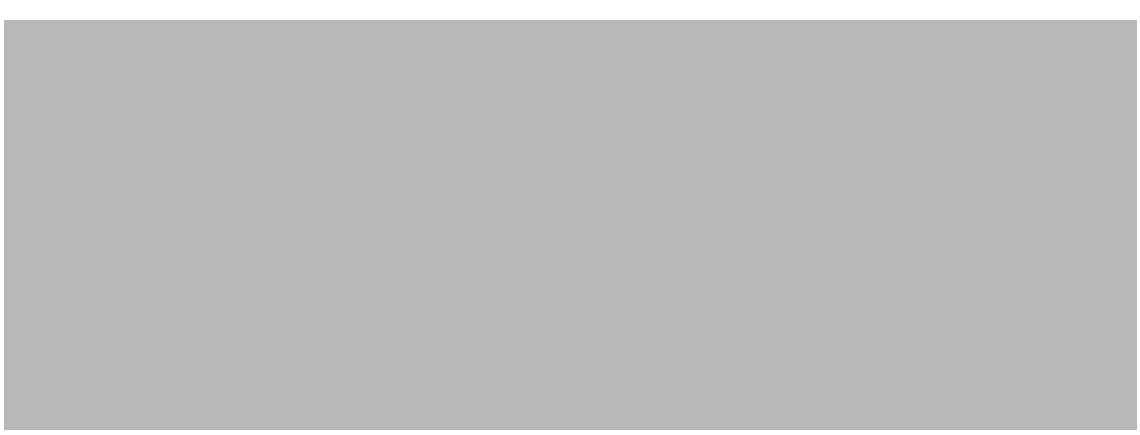

FIG. 9. RUHENTAL. THE PALACE. FAÇADE FACING THE COURTYARD WITH CROSS-SECTIONS OF THE WINGS (INK, WATERCOLOUR), $29 \times 81$. NM THC 1529.

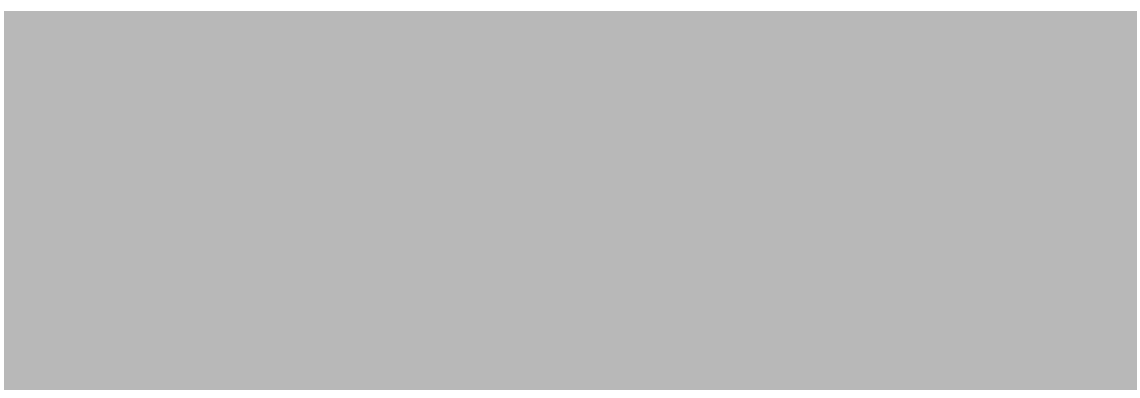

FIG. 10. RUHENTAL. THE PALACE. LATERAL FAÇADE (INK, WATERCOLOUR), $29,5 \times 90$. NM THC 1530. 
L'An 1734. However they began to build the palace only in 1736 and Biron became the Duke of Courland in 1737. Thirdly, the mature rococo cartouche frame could not be from the 1730s as Rastrelli's style, along with all other architects working in Russia or Courland at that time, was late Baroque. Rococo became characteristic of Rastrelli's oeuvres only from the 1750 s. This means that the inscription was added to the drawing not earlier than 1764, when Rastrelli continued his work in Courland ${ }^{25}$.

Thus the drawings of the Ruhental palace from the Albertina Museum are the original designs, while the sheets from the Bergholtz collection, which are not signed, not approved and not dated should be regarded as their copies. However a thorough pairwise comparison of the corresponding drawings reveals some differences between the sheets from the museums of Stockholm and Vienna. Both plans, courtyard façade and lateral façade from the Bergholtz collection exactly coincide with those from the Albertina Museum. Two other façades from Stockholm though generally identical to the corresponding Viennese sheets actually differ in some minor details, however very insignificant. Mostly they concern the images of allegorical statues with different poses and gestures. For example, on the original drawing of the garden façade a masculine figure on the pediment of the right wing is shown frontally facing the viewer and on the copy - in a three-quarter turn with his back to the viewer The rest few differences which one may find comparing two sets of drawings are even less notable.

Among the drawings of the Ruhental palace from the Bergholtz collection a separate place belongs to the general plan. It covers a slightly smaller area than the same plan from the Albertina Museum and it lacks the cartouche with the inscription. The territory of the estate is cut off from almost all sides, from the northeast in particular. While the palace, stable yard, French garden and hunting park are drawn with the same precision as the Viennese plan, a small orchard in a lower part of the sheet is shown more schematically. Nevertheless the situation plan from Nationalmuseum Stockholm should also be regarded as a copy of the original plan.
The designs of Francesco Rastrelli under review here were implemented with quite a high degree of precision. However, examining the projects and the present building one may point out some contradictions and variances (without knowing about later alterations). The most significant differences lie in the number of window axes that do not match the drawings and in situ. The lateral façades were intended to have 29 axes of openings including five at the central projection. While in fact there are 31 and 3 respectively. The same trait is characteristic of the courtyard façade of the Corpsde-Logis: 15 axes on both plans and 17 in situ (the same number as on the drawing of the façade). One can also note the different number of dormer windows on the roofs of the Corps-de-Logis and side wings as presented in the project and in the existing building respectively. These modifications of the initial plan were probably made by Rastrelli during construction of the palace between 1736 and 1740 . However, they are quite insignificant and in no way change the character of palace architecture.

In spite of the alterations and losses suffered by the building during the centuries the palace retains the main features of its original appearance, dating back to the 1730s. The first changes to Biron's summer residence took place in the 1760s during the second period of construction. In those years the gate tower on the entrance side of the palace was demolished and replaced by a gateway flanked by pylons crowned with lions. At present, not much survives from the interior decoration of the first period of construction. The most significant features are two grand staircases that appear on the cross sections of the lateral wings ${ }^{26}$. They were executed in 1739-1740 and are preserved completely intact today, showing the mature Baroque style of early Rastrelli. The spatial structure of the staircases corresponds to the project and the decorative motifs follow it, not accurately but in the same spirit. With a few exceptions the rest of the interior decoration is typical of the 1760s, or much later. It is worth mentioning that a great hall at the northeastern corner of the palace was initially intended to be occupied by a Lutheran church with a separate entrance for the parish. In 1736 Rastrelli invented a design for the high altar in the 


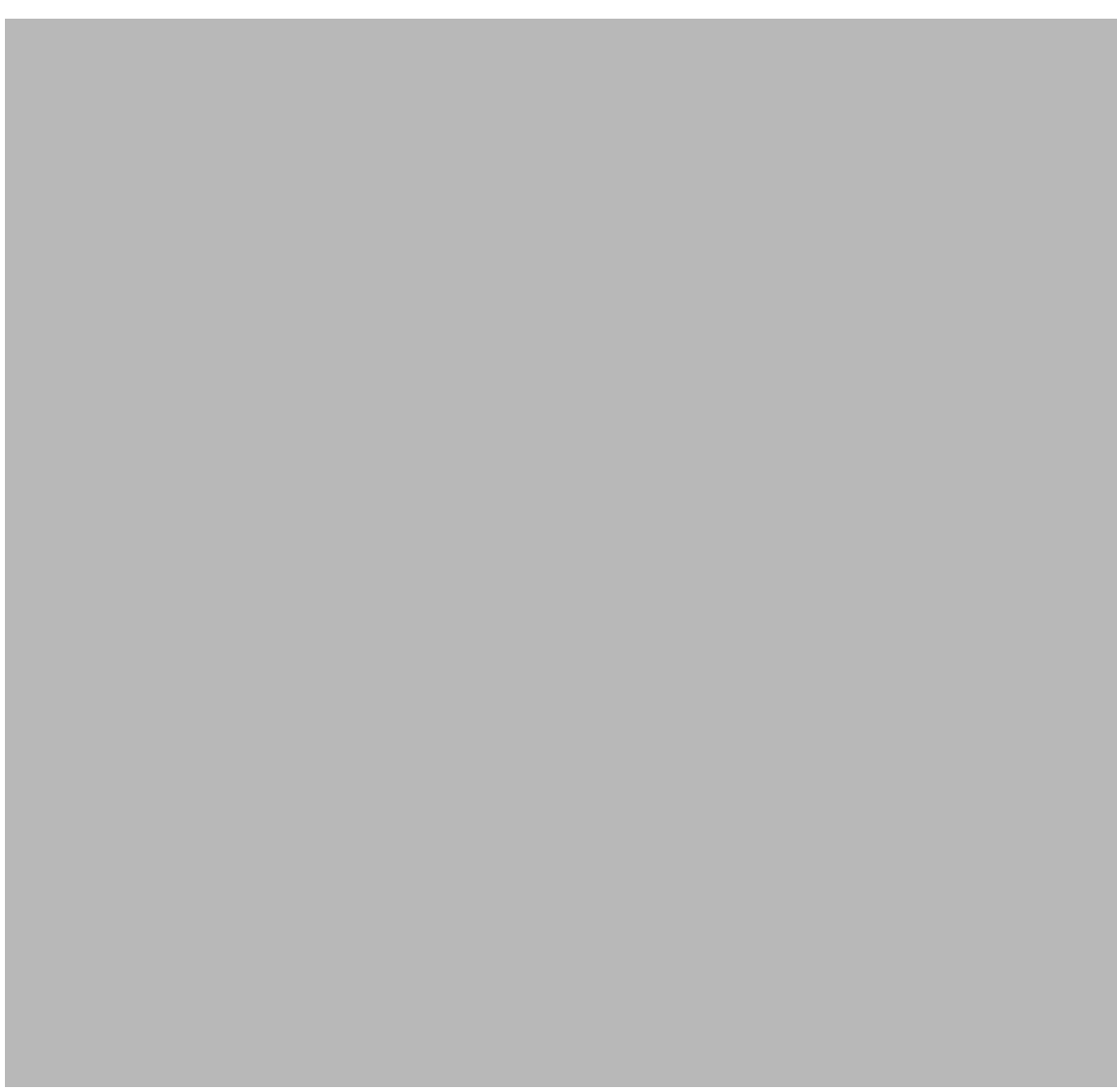

FIG. 11. MITAU. ALTAR IN THE PALACE CHAPEL (INITIALLY INTENDED FOR RUHENTAL) FRONT AND PLAN (INK, WATERCOLOUR), 75,5 × 77. NM THC 1969 .

Baroque style ${ }^{27}$ that had an extensive theological program typical of the Lutherans. But in 1740 Biron decided to locate the church in his city residence in Mitau; in Ruhental instead of the church a splendid white ball hall was constructed in the 1760s.

27 Albertina, 79-1-4. N 5682. This drawing was approved by Biron and signed by Rastrelli "De Rastrelly f. 1736". Later the project was destined for the palace in Mitau as evidenced by the title of the sheet in French: "Grand Autel du Palais Ducal a Mittea". A copy from the Bergholtz collection (unsigned and undated) has an inscription: "Abzeichnung des Altars in die Mietauischen Schloss Capelle" (NM THC 1969).
Finally, the stable yard, which is shown on two drawings (the general plan and the plan of the first floor) ${ }_{r}^{28}$ was started in the $1730 \mathrm{~s}$ although not completed before Biron's exile. During the second stage of construction in the 1760s the stable yard was built according to a new project which was a collaboration between Rastrelli and a Dane, Severin Jensen, a court architect of the Duke of Courland.

The drawings of the palace in Mitau (from the Bergholtz collection) show the plans of the ground and first floors and the main façade in two versions ${ }^{29}$. Both plans represent the palace as it was executed. One of the façades shows the palace as it was first conceived and is considered to be a copy of the first version by Rastrelli which is to be found in the collection of the Albertina Museum, Vienna ${ }^{30}$. The drawing from Vienna is dated to 1738 and is approved by Biron. One more copy is to be found in the National Library in Warsaw ${ }^{31}$. At the top of this sheet an inscription in French is placed: Nouveau Palais du Duc Courlande, Sous la Reigne de L'Imperatrice Anna qui à Été Bâtis á Mitteau ("New palace which was built by the Duke of Courland under the reign of the Empress Anna"). In spite of the Biron's approval and the above inscription this project has never been realized. Both plans of the Mitau palace stored in the collection of the Albertina Museum $^{32}$ correspond to this unexecuted project unlike those from the Stockholm museum.

The palace was built according to another version of the main façade from the Berholtz collection. It is easy to identify by comparing the drawing with the existing building and with the fixating drawing of about 1800, which shows the main façade and the plan of the ground floor $^{33}$. Regardless of later alterations, which all the main elements

28 Albertina, 79-2-5 N 5675, 79-2-6 N 5676; NM THC 1524, 1526

29 NM THC 1520, 1521, 1522, 1523. All the drawings have German inscriptions made mos probably by Bergholtz himself. The inscriptions are as follow. N1520: "Grund Riss, / Der unterste Etage, Des Hochfurstichen, Mitauischen Schlosses, wie solches, von dem damahligen Herzog von Biron, Angeleget, und vor dessen fall, biss unter Dach gebracht worden". N 1521. "Grun Riss, Der Obersten Etage, Des vorgedachten, Hochsurstichen Mitaulschen Schlosses". N 1522: "Das herzogliche Mietauische Slos, nach dem Ersten Projekt" N 1523: "Des Hochfürstliche "Ditauischen Pallais, in Courland".

30 Albertina, AZ5674.

31 Biblioteka Narodowa (Warszawa). Magazyn ikonografii, R.5409/WAF.104. It is published in: Krystyna Gutowska-Dudek, Rysunki z wilanowskiej kolekcji Potockich w zbiorach Bibliotehi Narodowej. Catalogue, III (Warszawa: Warszawa Biblioteka Narodowa, 2002), 22, 23.

32 Albertina, 79-1-4 N 5672, 5673.

33 Russian State Historical Archive [RGIA], f. 1399, op. 1, d. 441, 1. 4 


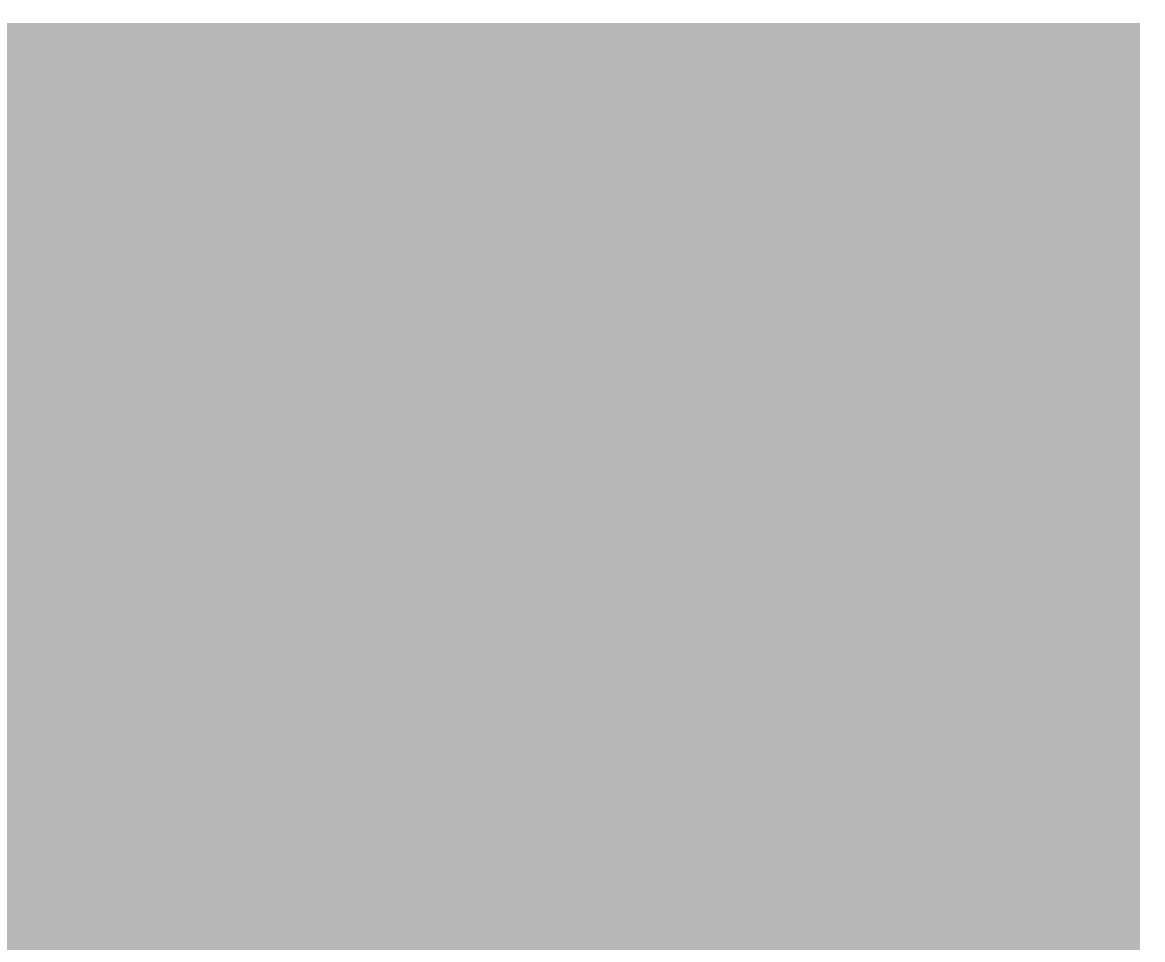

FIG. 14. MITAU. THE PALACE. FAÇADE (FIRST VARIANT) (INK, WATERCOLOUR), $36 \times 188$. NM THC 1522.

IG. 15. MITAU. THE PALACE. FAÇADE (FINAL VARIANT) (INK, WATERCOLOUR), 40,5 × 192 NM THC 1523.

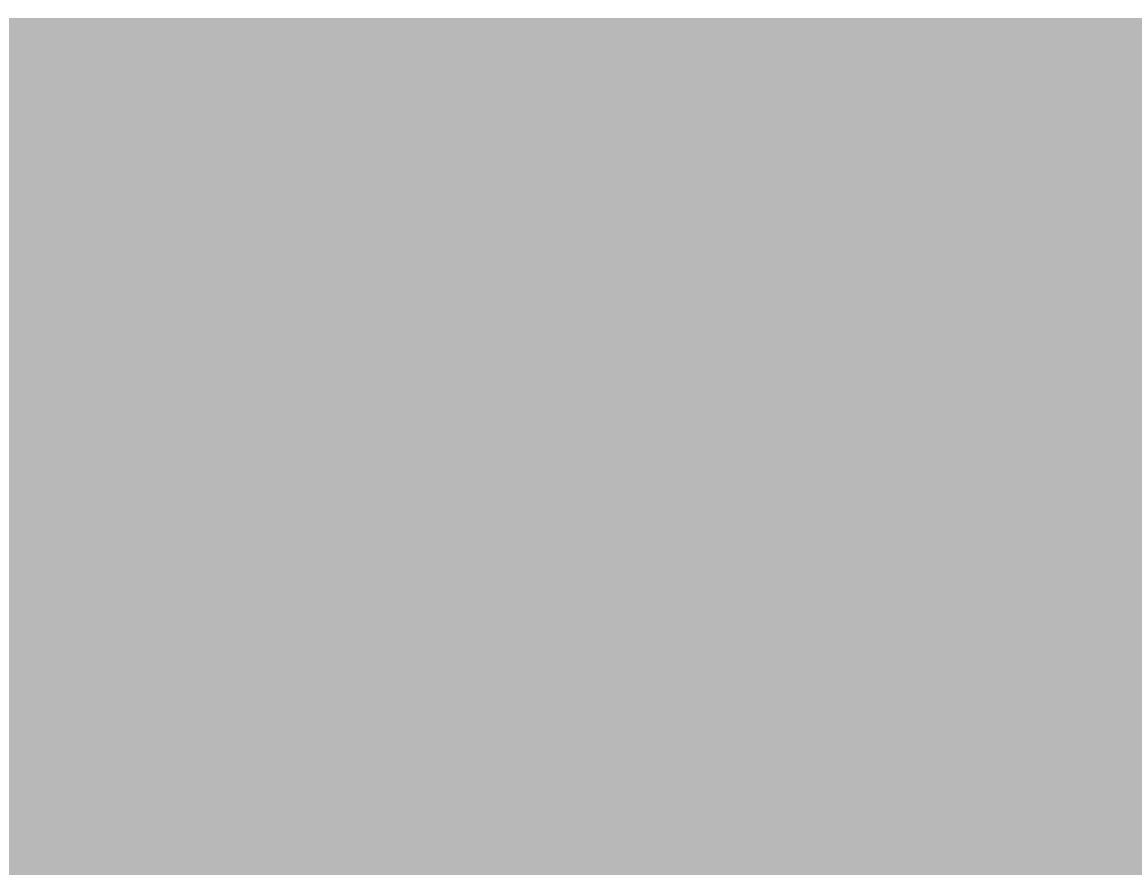

FIG. 12. MITAU. THE PALACE. PLAN OF THE GROUND FLOOR (INK, WATERCOLOUR), $63,5 \times$ 76. NM THC 1520

THE PALACE. PLAN OF THE FIRST FLOOR (INK, WATERCOLOUR), $62,5 \times 80$ NM THC 1521. of the palace structure experienced, elevations and decorative motifs have been preserved. Thus this version of the façade, and both plans, are of great value as they are the only existing (known) drawings representing Rastrelli's final realised project. In other words the above-mentioned drawings from the Bergholtz collection are copies of original Rastrelli designs that remain undiscovered. However, one may trace some mismatches between the project and the existing building as was the case with the palace in Ruhental. For instance, the courtyard façades of the lateral wings have fewer windows than appear on the plans. The lateral wings became shorter and the proportions of the courtyard were revised. Notwithstanding this, the drawings in general truthfully depict the palace as it was built, under the orders of Biron before his fall in 1740. As evidenced by the inscription on the plan of the ground floor made by Bergholtz, the palace at that time was 'brought under the roof' (biss unter Dach gebracht worden), meaning that statues, dormers and pediments with coats of arms and sculptural compositions were probably not implemented. 

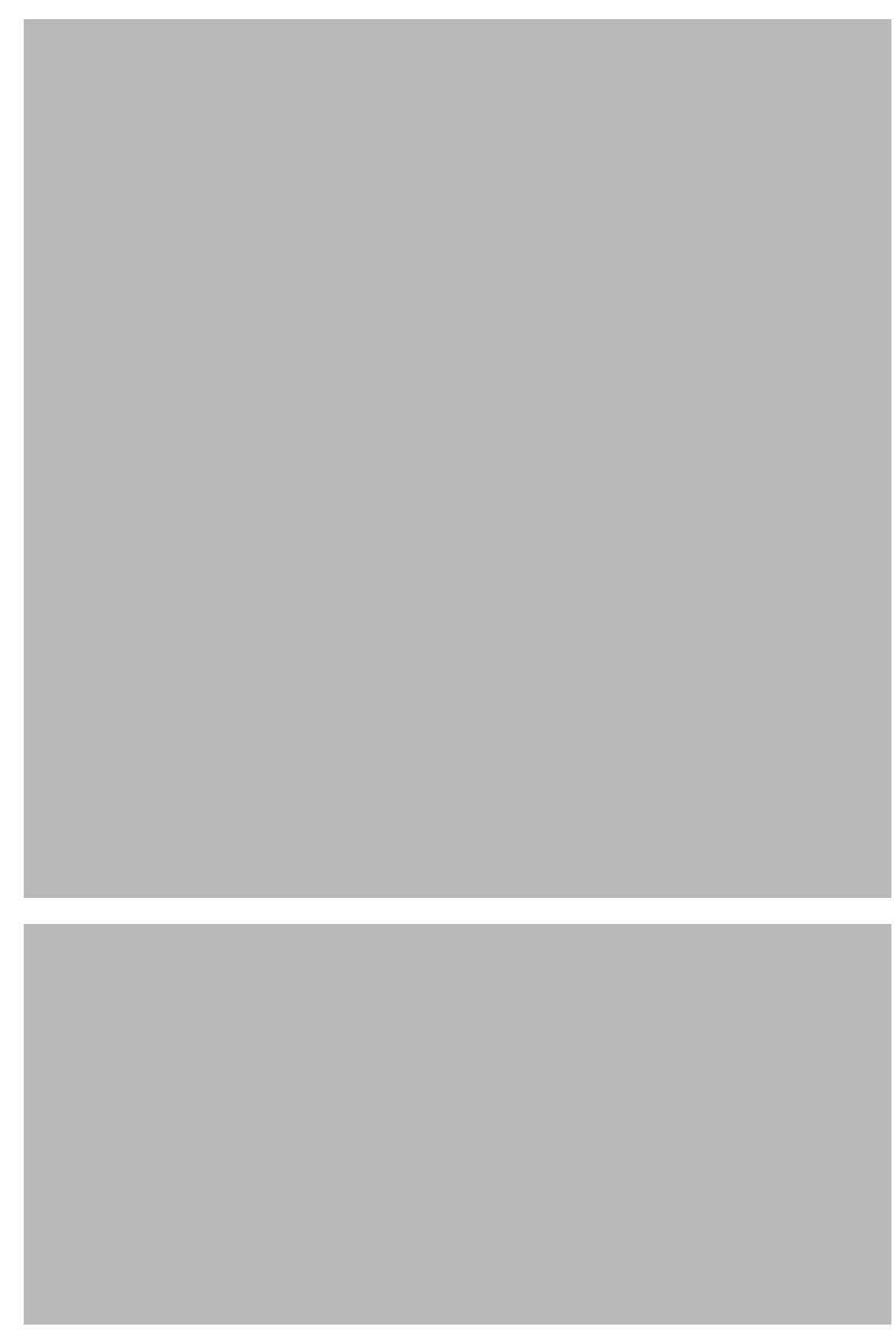

FIG. 16. RUHENTAL. THE PALACE AND THE GARDEN. GENERAL PLAN. ALBERTINA, 79-2-5 N 5675.
FIG. 17. RUHENTAL. THE PALACE. GARDEN FAÇADE. ALBERTINA, 79-2-9 N 5679.

FIG. 18. RUHENTAL. THE PALACE. NORTHERN FAÇADE WITH A GATE-TOWER. ALBERTINA,

79-2-11 N 5681.
FIG. 19. MITAU. THE PALACE. PLAN OF THE GROUND FLOOR. ALBERTINA, 79-1-4 N 5673.

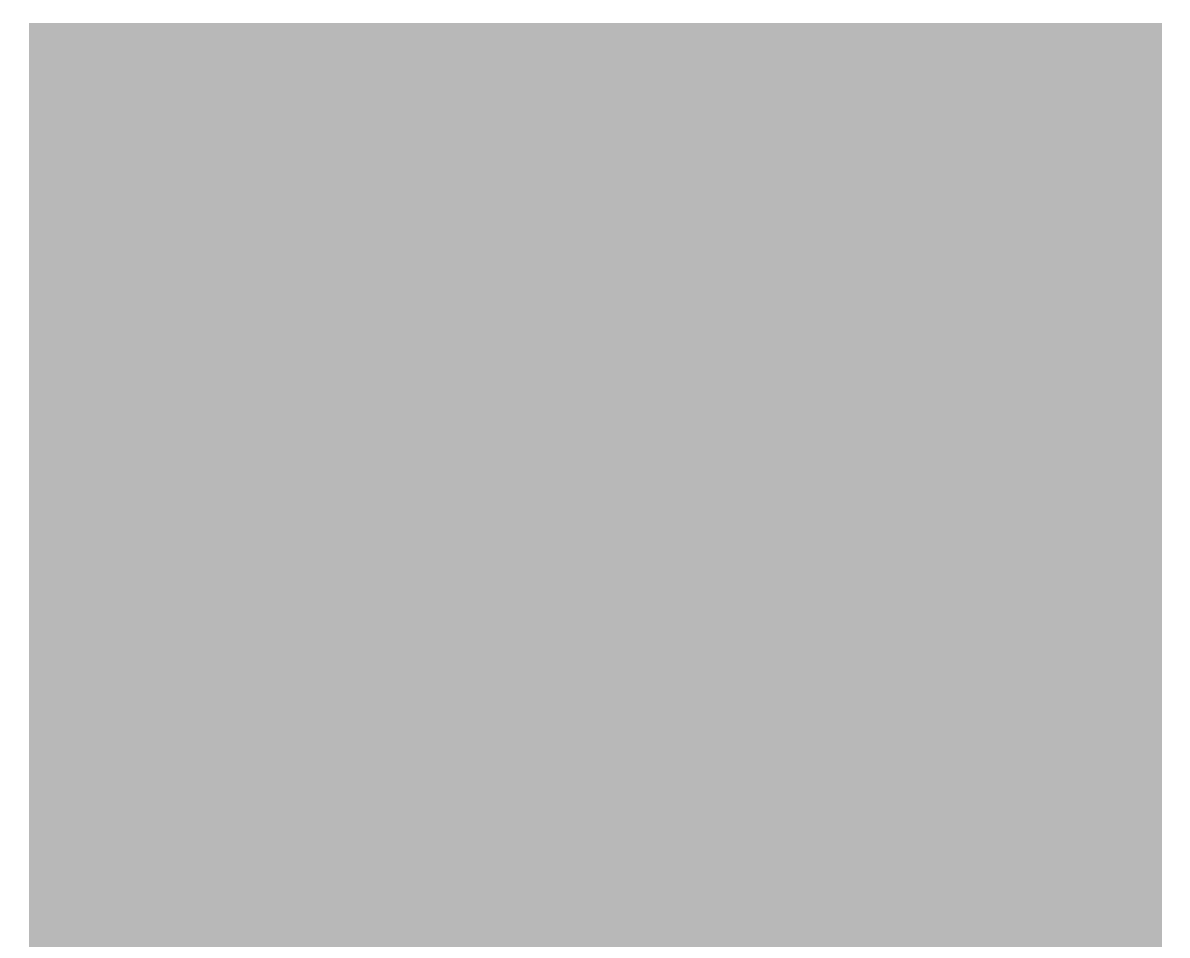

FIG. 19. MITAU. THE PALACE. PLAN OF THE GROUND FLOOR. ALBERTINA, 79-1-4 N 5673. 


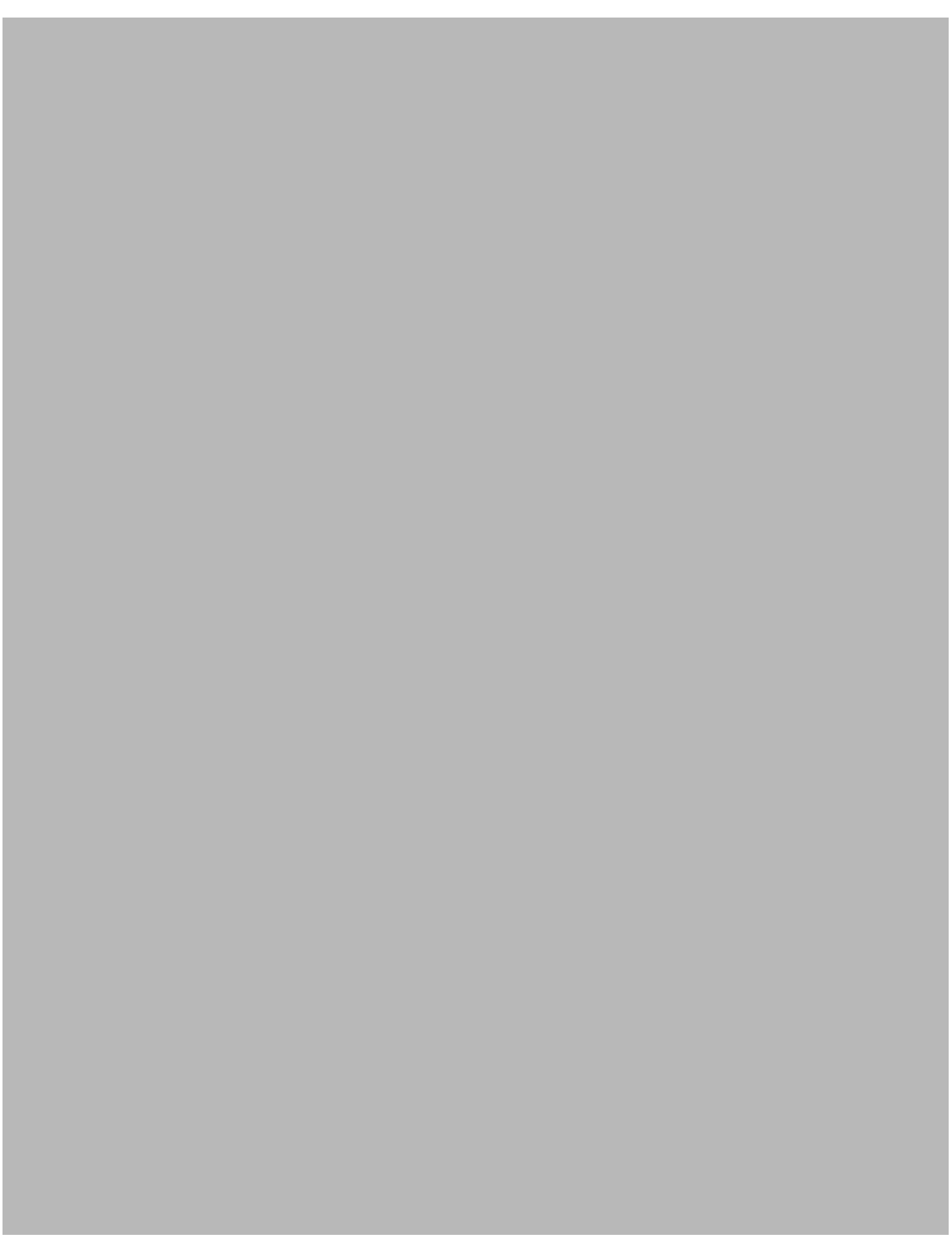

FIG. 20. MITAU. THE PALACE. FAÇADE AND PLAN OF THE GROUND FLOOR (INK WATERCOLOUR). RGIA, F. 1399, OP. 1, D. 441, L. 4.
After Biron's return from exile the changed artistic taste demanded stricter and simpler forms of nascent neoclassicism. The influence of the new style was mainly reflected in the upper parts of the building, which were deprived of intricate and fancy Baroque elements. For example, the broken segmental pediment of the central projection of the main façade had a stricter shape, and later, by 1800, was replaced by a triangular pediment. Clusters of pilasters on the same projection were replaced by more balanced pairs of pilasters. The lateral projections were deprived of mezzanine storeys and crowned with triangular pediments. Obviously the entire sculptural program was not implemented, although cast iron lion masks and plant ornaments produced at Rodion Batashev's factory in Tula, initially designed for Ruhental, were used according to Biron's order for the decoration of the palace in Mitau.

The internal layout was mainly carried out in accordance with the original project. However, in the late $18^{\text {th }}$ century two significant alterations were made, reflected on the fixating plan of about 1800 . Firstly, the church was divided into several small rooms after the death of the dowager Duchess Benigna Gottlib Biron (1782). Secondly, the grand staircase was restored in a thrice reduced shape after the fire of 1788 .

It should be noted that the palace has received its present appearance as a consequence of renovation and reconstruction over the centuries of its existence, and due to the conservation work that took place after damage in the Second World War. For these reasons the discussed drawings are very helpful in the reconstruction (at least theoretically) of the original architecture of the palace in Mitau. 
Georgy Smirnov, Tatyana Vyatchanina: The Bergholtz Collection: Architectural Drawings of the Palaces in Jelgava and Rundale from Nationalmuseum (Stockholm)

Keywords: architecture; palaces of Biron; Baroque; Rastrelli; Bergholtz collection; Nationalmuseum in Stockholm; Albertina museum

\section{SUMMARY}

The article deals with two Courland palaces built by the Duke Ernst Johann Biron in Mitau and Ruhental (today, respectively, Jelgava and Rundale, Latvia) in connection with architectural drawings of the so-called Bergholtz collection, which is part of the Tessin-Hårleman Collection (THC) in Nationalmuseum in Stockholm. Twelve drawings of the two Courland palaces make this collection of special interest to those interested in the art of the Baltic region.

The first part of the paper is dedicated to the person of Friedrich Wilhelm von Bergholtz and to his collection. Who was the creator of the collection, what were the reasons to gather it and what other drawings are stored there? Born in the German duchy of Holstein, Bergholtz spent in all about 15 years in Russia. An extremely rich and diverse collection of architectural drawings was gathered mainly (presumably totally) during his third visit in 1742-1746 as tutor of Karl-Peter-Ulrich, heir to the Russian throne and future emperor of Russia under the moniker Peter III. The circumstances of compiling the collection and reasons for it are quite obscure. All the assumptions made by different authors remain mere guesswork. The greater part of the Bergholtz collection deals with St Petersburg and its surroundings. All other drawings, numbering 174 in total, refer to Moscow, to several provinces of the Russian empire and to the Duchy of Courland.

The second part of the article reveals and describes 12 sheets from the Bergholtz collection dedicated to the Baroque palaces in Courland constructed in the 1730s for duke Ernst Johann Biron according to the projects of the great architect Francesco Rastrelli. The research resulted in the discovery of seven sheets depicting plans and façades of the palaces in Ruhental, showing how they are almost exact copies of the original projects stored in the collection of the Albertina museum in Vienna. Of the five drawings that represent the palace in Mitau, two are also copies of the Vienna sheets, and three are copies of completed projects. Thus, the most valuable among the architectural drawings from the Bergholtz collection are three drawings depicting the façade, and plans for two floors, of the palace in Mitau - the only known copies of Rastrelli's project, the originals of which have not yet been discovered.

CV

Georgy Smirnov is the leading researcher at the Department of the Inventory of Historic Buildings at the State Institute for Art Studies in Moscow. He studied art history at the University of Moscow. In 2003, he received a PhD with a work titled Architecture of Public Buildings in Russian Provincial Towns in the 2 nd Half of the $18^{\text {th }}$ century. His main fields of research are Russian $18^{\text {th }}$ century architecture (especially Baroque and Neoclassical) and Central Europe in the $16^{\text {th }}-18^{\text {th }}$ centuries. Smirnov has released numerous publications on the history of Russian architecture and Baroque architecture in Central Europe. Recent publications include: Inventory of Historic Buildings and Monuments of Russia. Tver Region (Svod pamyatnikov arkhitektury I monumentalnogo iskusstva Rossii. Tverskaya oblast), vol. 1-4 (ed. by G. K. Smirnov, 2003-2016); History of Russian Art, vol. 13. Russian Provincial Art of the Second Half of the $18^{\text {th }}$ century (Istoriya rysskogo iskusstva, Tom 13. Provinzialnoe iskusstvo vtoroi poloviny 18 veka) (ed. by G. K. Smirnov, under completing).

Tatyana Vyatchanina is the Deputy Director of research at the Research Institute for the Theory and History of Architecture and Urban Planning; and adviser to the Director of the Central Scientific and Restoration Project Workshops for scientific and publishing activities Moscow.

T. Vyatchanina studied art history at the University of Moscow. In 2009 she received PhD in Art history with "The Spiritual Foundations of Architectural Forms in the Church Architecture of Ancient Russia". Her main fields of research are the theory of reconstruction and restoration of architectural monuments, and the history of Russian 
Mediaeval architecture. Vyatchanina is the author of a significant number of scientific and research publications on the history of Russian architecture and heritage conservation. Among them are: $O n$ the Iconography and Tectonics of the Orthodox Temple; Monuments in Prerevolutionary Russia: Essays on the History of Architectural Restoration; and numerous articles in periodicals and scientific collections, for example "Architectural Heritage", "History of Architecture in the History of Culture", "Academia", "Restoration and Research of Cultural Monuments", etc. 